\title{
9
}

\section{Multiculturalism Policies and the Stepwise International Migration of Filipino Nurses: Implications for Japan}

\author{
Maria Reinaruth D. Carlos
}

\subsection{Introduction}

As a result of globalization, labor migration and migrant integration are inevitable yet uncomfortable bedfellows. From the point of view of the host society, the entry of workers from another nationality or culture might solve a domestic labor shortage, but at the same time it will raise serious questions regarding how migrants can be integrated in the society. In what aspects of the community and to what extent will they be allowed to participate in the host society? Multiculturalism policies have been established as frameworks for integration; some have earned praise for their success in some migrant-receiving countries and endured criticisms in many other countries. This chapter presents the case of stepwise migrant nurses from the Philippines to provide one perspective on how multiculturalism policies becomes important predictor of the pattern of international labor migration.

The objectives of this chapter are three-fold: (1) to examine the stepwise migration behavior of Filipino nurses, especially how and why it happens; (2) to determine how multiculturalism policies impact the choice of transit and final destinations in the process of stepwise migration; and (3) to look at the links between stepwise migration and multiculturalism policies, specifically in Japan, which has begun accepting Filipino nurses under a government-to-government arrangement called the Japan-Philippines Economic Partnership Agreement (JPEPA). Given the tendency toward stepwise migration among Filipino nurses, the weakness of the JPEPA scheme as a source of a stable longterm nursing workforce, and the limited capability of the Japanese government to effectively and immediately implement "top-down" 
multiculturalism policies, this chapter suggests a strategy of encouraging circular migration of foreign nurses in order to alleviate shortage of nurses in the future and at the same time to promote multiculturalism in this country.

An emphasis of this chapter is on the "stepwise" migration of nurses, where they sequentially work in several countries as transit points or stepping stones until they reach their most preferred and final destination. The "stepping stone" strategy has been mentioned in several previous works on nurse migration (see Buchan, Jobanputra \& Gough, 2005; Buchan et al., 2005; Dumont \& Zurn, 2007; Kingma, M., 2008; Matsuno, 2009), but few have elaborated on how and why this phenomenon occurs. Nurses from the Philippines do follow (and are likely to follow) the stepwise migration pathway. By going through several transit points rather than straight to the most preferred destination, they are able to use their time efficiently while waiting for opportunities in the most desired destination and to accumulate resources-human, financial, social, and political—for use in the transit points or to be transferred to the next destination.

There is also the question of how stepwise migrants distinguish between a transit destination and a final one. This is particularly relevant considering the emerging issue of nurse retention. Two factors prompt stakeholders' deep concern on the retention issue. First, in light of the aging population, it is important to have a stable source of experienced nurses in the workforce. Therefore, ongoing training of foreign-educated nurses can be one strategy for overcoming future projected shortages. Second, training nurses takes time and incurs costs, and the longer the nurse stays, the higher the possibility of recovering this investment. Even in Japan, the attention of policymakers and those on the ground has been gradually shifting from recruiting and employing foreign nurses to retaining them in the workplace.

The multiculturalism policies (or lack of them) that nurses consider important in their choice of final or transit destinations are explored in this chapter. Specifically, three basic components or aspects of multiculturalism policies and practices will be investigated, namely, (1) access to labor markets and equal treatment of locals and foreigners in the workplace, (2) access to citizenship, and (3) family reunification. These multiculturalism policies on the national level as well as multicultural practices in the workplace influence migrant decisions through their impact on the economic (salary, labor conditions, and security of tenure) and social (availability of family support, recognition, sense of 
self-worth, and belongingness in the workplace) determinants of stepwise migration.

Japan began receiving foreign nurses in 2008 under a governmentto-government economic partnership agreement. Under this scheme, nurses from the Philippines and Indonesia are initially accepted as "candidates," and their stay beyond three years is only permitted if they pass the National Licensure Examination conducted in the Japanese language. Five years have passed, but the results are very limited in terms of the number of nurses who were recruited, the number who qualified to stay beyond three years, and the number of those who chose to stay after getting the Japanese license. While multiculturalism policies are deemed important in attracting and retaining foreign nurses in this country, their formulation and more so their implementation has been slow, primarily because of the political, economic, and social implications, of which the Japanese stakeholders are wary. Given these domestic circumstances, coupled with the tendency for Filipino nurses to engage in stepwise migration, this chapter suggests the alternative, albeit mid-term, measure of encouraging "circular migration." This will not only create a stable pool of foreign nurses, but also introduce and contribute to multiculturalism on the ground (multiculturalism from below). This undertaking, in turn, can be an instrument for this country's national and local governments to initiate complementary "top-down" multiculturalism policies.

The empirical evidence on the dynamics of the stepwise migration pattern and its relationship with multiculturalism will be drawn from data gathered from fieldwork conducted in Singapore, Australia, the UAE, Japan, and the US. The fieldwork component comprises two parts: (1) implementation of a common survey questionnaire (through snowballing), with a few items redesigned to be compatible with the current labor migration policies of a specific destination; and (2) semistructured interviews with some of the respondents and stakeholders. The questionnaires were implemented as follows: Singapore (March 2010, March 2011); Dubai, the UAE (October 2010); and Sydney and Darwin, Australia (October 2012). The numbers of nurse respondents ${ }^{1}$ are as follows: 72 in Australia, 53 in Singapore, and 48 in the UAE. In the US, interviews with stakeholders were conducted in June-July 2012 in Washington DC, Los Angeles, CA, and Union, NJ. Information on multiculturalism policies, immigration rules and procedures was taken mostly from announcements in official government websites and newspapers. 
This chapter is organized as follows: in the next section, the analytical frameworks on stepwise migration, multiculturalism, and multiculturalism policies to be used in this chapter will be presented. In Section 9.3, results of a study on the working of stepwise migration are analyzed, followed in Section 9.4 by a discussion of how multiculturalism policies affected nurses' choices of transit and final destinations. In Section 9.5, Japan's current scheme for accepting Filipino nurses is examined from the perspectives of its labor shortage of nurses and multiculturalism. The final section summarizes and concludes this chapter.

\subsection{Analytical framework-stepwise migration and multiculturalism}

Simply defined, stepwise international migration is a pattern, pathway, or strategy in which migrants move from one transit country (the stepping stone) to the next until they reach the most preferred destination. It is a series of rational decision-making processes that involve constantly assessing the labor and migration conditions and policies in several destination countries as well as the migrants' own capabilities and resources with the objective of moving to a better or more preferred destination, until the most preferred final destination is reached (Carlos \& Sato, 2010, 2011).

A stepwise migration pattern differs from the conventional patterns of migration in three ways. First, this migration pattern consists of multiple stages, with the migrant's movement from one stage (destination) to another following some form of hierarchy. This differs from a one-time movement from the origin to the destination by permanent migrants or from circular migration wherein the migrant moves back and forth between one origin and one destination. Second, stepwise migrants are not simply "transients" who spend just a week or a month in one destination. Third, this pattern has a dynamic nature in which the migrants themselves actually make a series of decisions-either at the beginning of their journey (departure from the source country) or along the way to the most preferred and final destination. Their journey may be planned, to some extent, from the beginning, but it may also be unplanned (Paul, 2011).

Recent empirical studies, such as Carlos and Sato $(2010,2011)$ and Paul (2011), show that nurses' decisions on how they treat a destination depends on the country's economic performance, its historical and political affiliation with the sending country, and its ambiguous and unpredictable policies on the recruitment and employment of foreign 
workers. This chapter looks at multiculturalism policies in the destination as another important factor that strongly influence the migrant's decision on whether to stay in one destination or to leave for the next one.

The concept of multiculturalism was introduced in the 1960s, and in the years that followed debates on what multiculturalism is and why and how it should be implemented have gradually become the center of discussions about migrant integration. In recent times, the 9/11 incidents in the US and social unrest involving migrants in France and Germany necessitated the re-examination of multiculturalism as a form of integration. Some alternative, but equally controversial, ideas such as "interculturalism," "civic integration," and "social cohesion" have been introduced. They are not completely distant in meaning from multiculturalism, but they build on, and are therefore, compatible with multiculturalism. Moreover, multiculturalism programs and practices have only changed their titles, and are still based on the same ideas and principles (Banting \& Kymlicka, 2012, p. 15; Cantle, 2012).

The working definition of multiculturalism that is adopted in this study is derived from Tariq Modood:

Multiculturalism refers to the struggle, the political mobilization but also the policy and institutional outcomes to the forms of accommodation in which "differences" are not eliminated, are not washed away but to some extent recognized. Through both these ways, group assertiveness and mobilization, and through institutional and policy reforms to address the claims of the newly settled, marginalized groups, the character of "difference" is addressed; ideally, a negative difference is turned into a positive difference, though in most contemporary situation(s), something of each is likely to be simultaneously present [emphasis added]. (Modood, 2013, p. 36)

For Modood, multiculturalism is one mode of integration, ${ }^{2}$ in which cultural, political, and other forms of (negative) differences, as identified both by the integrating group (often the newly settled minority) and the other groups (majority and the "traditional" minority groups), are recognized and put to use for the good of the larger group (positive difference). Moreover, these differences are addressed by using two main tools, as follows: through assertion by and mobilization of all groups (not only the integrating group), and through the implementation of a set of policies by the government on the national and local levels. Effective multiculturalism policies should not be meant to eliminate differences among the groups; instead, they should cultivate a vision for 
the common good of the multicultural society despite these differences. Neither is multiculturalism a "cure-all" prescription to prevent and resolve conflicts among groups in a society. Furthermore, to be able to channel negative differences into positive differences, groups should not just be recognized but also appreciated so they can feel a greater sense of belonging and thus dedication to the common good.

In reality, however, it is difficult to differentiate multiculturalism policies from other types of policies related to immigration. In the opinion of Banting and Kimlycka (2012), "there is no universally-accepted definition of 'multiculturalism policy' and there is no hard and fast line that would sharply distinguish multiculturalism policies from closely related policy fields, such as anti-discrimination policies, citizenship policies and integration policies" (p. 6). Therefore, we define multiculturalism policies on a broad spectrum; that is, as a wide range of policies that can be employed to accommodate new group identities and new norms in the public sphere. Furthermore, we limit our analysis to the following three areas of multiculturalism policies: (1) access to labor market and equal rights and benefits in the workplace, (2) access to citizenship, and (3) family reunification. These three areas are the most essential components of multiculturalism policies that motivate foreign workers in general and stepwise migrant nurses in particular to stay in a destination. ${ }^{3}$

\subsection{Stepwise migration among Filipino nurses}

This section will discuss how and why stepwise migration has become a common practice among Filipino nurses, as indicated by the results of the fieldwork in three destinations.

\subsubsection{Do Filipino nurses engage in a stepwise migration strategy?}

In order to determine whether Filipino nurses engage in stepwise migration, we first inquired about their work experience before coming to the current destination. The survey results show that some respondents have worked in countries outside the Philippines at least once. The percentage of those who have work experience abroad is highest for Australia at $35.4 \%$, followed by the UAE (31.9\%), and then Singapore (15.4\%). In addition, whereas all respondents in Singapore had some work experience in the home country, some nurses in Australia and the UAE did not have any. This is because in Australia and the UAE, alternative migration pathways other than obtaining a working visa, 
for which a Philippine license is often required, are available to Filipino nurses, as mentioned above.

Another interesting trend is that the majority of those who had experience working outside the Philippines had previously been based in the UK, Ireland, the Kingdom of Saudi Arabia (KSA), and other counties in the Middle East. Of these countries, the KSA emerged as the most popular, with the exception of the UK for nurses based in Australia. Apparently, this is because the KSA has been actively recruiting nurses from the Philippines since the 1970s. From 2004 to 2010, about $70 \%$ of all newly hired nurses processed by the Philippine Overseas Employment Administration (POEA) were deployed to this country (Philippine Overseas Employment Administration, n.d., Table 14). Having easy access to nursing jobs in the KSA through POEA-accredited recruitment agencies, fast processing and immediate deployment at an affordable cost largely contribute to its popularity as an initial destination. ${ }^{4}$

For those currently working in Australia, the UK (18.5\%) and Ireland (9.2\%) also emerged as formerly popular places for Filipino nurses to work. These countries faced nurse shortages from the late 1990s until the mid-2000s, and they allowed entry of Filipino nurses on work visas that could later be converted to permanent residency visas and then citizenship. Their numbers peaked in 2001 and declined thereafter, when despite, the bilateral agreement on the recruitment of Filipino nurses forged by the two governments in 2002, recruitment was unilaterally stopped by the UK government, to the surprise of the Philippine government. There were two reasons: self-sufficiency in their nursing workforces has been achieved and there was competition from nurses coming from within the EU (Carlos, Sato \& Caragay, 2009, pp. 77-81).

\subsubsection{How do Filipino nurses engage in stepwise migration?}

To further understand how stepwise migration took place among the nurses in this study, their pathways and period of stay in each destination was mapped (see Appendix Table A9.1). The results revealed two trends. First, migrant nurses stay in one destination for a considerable period, usually years. This length of stay is necessary because the resources required to move to the next destination often take time to accumulate, particularly human and political resources (i.e. experience, skills, and citizenship). For nurses currently in Australia, the longest times spent in previous destinations were 13 years in the KSA, 11 in Libya, and 11 in the UK. Stepwise migrant nurses in the UAE also spent as long as 15 years in the KSA. On the other hand, very few respondents in Singapore had more than 5 years' experience in other countries. 
Second, compared to those who are based in Singapore and the UAE, many who now work in Australia had passed through several transit destinations, the most popular being the UK and Ireland. One interviewee who left the Philippines in 2000 said that compared to those originating directly from the Philippines, "it was much easier and less expensive to come to Australia with the UK passport, UK experience, and a UK nursing license." Given these advantages, we can infer that Filipino nurses who possess a passport from the UK or Ireland are more likely to engage in stepwise migration to Australia.

\subsubsection{Why do Filipino nurses engage in a stepwise migration strategy?}

Evidently, the tendency for nurses to take a roundabout pathway and pass through several transit destinations instead of heading directly to the most preferred final destination is a rational strategy. It allows for the accumulation of resources in the transit destinations that are not readily available in the Philippines but are required in the more preferred destinations. Moreover, it is seen as a rational strategy in light of the unpredictable and ambiguous nurse-migration policies of these destinations.

The findings imply that transferrable and useful resources in the forms of human resources (skills and license, as mentioned above), economic resources, social networks, and political resources (citizenship) can be accumulated in an previous (initial and transit) destinations, motivating nurses to work there first and engage in this stepwise strategy. In a focused group discussion (FGD) conducted among respondents who engaged in stepwise migration (Darwin, October 25, 2012), the nurses admitted that having several years of experience in one transit destination was much more preferred over the experience obtainable in the Philippines. Moreover, having a license appears to be a valuable asset in some cases because it enables the nurse to work right after arrival in a more/most preferred destination. Employers prefer nurses who have work experience overseas because it is considered proof of better nursing skills and knowledge, familiarity with modern medical instruments, and ability to work in a multicultural setting. Indeed, Filipino nurses target human resources in the destination to make them more marketable in the next destination.

The nurses also accumulate the economic resources to cover the expense of moving to the next destination, such as recruitment fees, examination and review fees, settlement costs, and transportation costs. Because of the low salary of nurses in the Philippines, these nurses prefer to work outside the country for much higher pay so they 
can save for such expenses. Social networks (social resources) in the destination-such as Filipino friends and families, the Filipino community in general, international recruitment agencies, and co-workers from different countries-can also be easily accessed from a destination. These networks can provide more accurate information about other destinations, although recently the Internet has also become a source of information for recruitment, and about life and work in potential destinations. Some international recruitment agencies choose to establish temporary and permanent offices in the destinations rather than in the Philippines to avoid being subjected to the strict recruitment regulations of the Philippines and because employers prefer nurses with experience working overseas.

Most of all, many of the respondents value the citizenship (i.e. political resource) obtained in the destination through naturalization because this becomes a way for easy access to and more favorable employment conditions in the next destination. Traditionally, obtaining citizenship in a destination is highly valued by migrants because it will give them equal rights and privileges under the law of the destination country and will allow them to settle permanently without migration restrictions. Many destination countries also use citizenship to attract and retain foreign nurses. In the case of the Filipino nurse respondents, however, citizenship in a destination is even more significant because it enables them to enjoy the rights and privileges accorded by some other destinations to citizens of the country where they are naturalized.

As one example, several Filipino nurse respondents in Australia have acquired prior citizenship in the UK, which was advantageous in finding work in Australia and settling there. A respondent in Dubai planned to work in the UK, apply for citizenship, and then return to the UAE because by doing so she would receive a higher salary and could petition for her family's entry more easily than could her fellow Filipino nurses in the UAE. Another respondent from Australia pointed out that she wants to work in the KSA temporarily because her Australian citizenship and nursing license enable her to receive a salary and benefits that are tax free and much higher than that usually earned by Filipinos in the KSA. In contrast to the common notion that a migrant will stay if she becomes a naturalized citizen of the host country, the nurses in the study instead consider such access to citizenship as a way to move on to another destination.

Moreover, the time spent in one destination, which is considerable, is explained by the unpredictable labor migration policies in many preferred destinations. Whether, when, and how to recruit and accept foreign 
nurses is singlehandedly decided by stakeholders in these destinations. Respondents pointed out that staying in one destination is an efficient and effective way to spend time while waiting for the opportunity to work in the most preferred destination, which depends largely on immigration policy reforms that may take years to be approved. For example, the current visa retrogression policy (US Citizenship and Immigration Services, 2013) of the US prevents entry of Filipino nurses, despite them meeting requirements such as passing the Visa Screen Program administered by the Commission on Graduates of Foreign Nursing Schools (CGFNS) International and National Council Licensure Examination for Registered Nurses (NCLEX-RN). Instead of staying in the Philippines, many of them grab the opportunity to work first in a less preferred destination with migration that is more restrictive and labor conditions that and worse and have lower pay, but which has a shorter processing time and requirements that are easier to meet. Indeed, when the respondents were asked about their top three reasons for working in the current destination, $71.7 \%$ of those in Singapore and $59.6 \%$ of those in the UAE chose "having the opportunity because this country actively recruits nurses from the Philippines." In contrast, only $11.3 \%$ of the respondents from Australia chose this response. This finding confirms that countries that actively recruit nurses from the Philippines easily become immediate or initial transit destinations for its nurses, but not necessarily their final destination.

Finally, the fact that nursing is a relatively global profession also contributes to the feasibility of stepwise migration. Nursing skills and knowledge have basic commonalities in many countries, allowing their accumulation and transferability among destinations. There are countries where the license is honored under a mutual recognition scheme so that nurses can begin working with minimal orientation from the new employers. Such is the case in Australia for licenses obtained in the UK (as explained above), Ireland, and New Zealand. The licensure or board examinations act as an objective way of assessing the nursing skills and knowledge accumulated elsewhere and evaluating their transferability across countries.

From these findings, it can be inferred that there is indeed some sort of hierarchy in the preferred destinations of stepwise migrants. However, such rankings do not seem to be determined prior to their first departure from the Philippines, and they will go wherever there is an opportunity to work. As they move along their stepwise pathway and accumulate resources overseas, the succeeding decision-making process to determine whether to stay or move and when to move to the next destination becomes more systematic and predictable. 


\subsubsection{To stay in the current destination or move to the next one?}

To further verify whether the current country is a final or a transit destination, the respondents were asked about their future plans. The responses show that while only $8 \%$ of the respondents in Australia had plans of leaving that country to work in another destination, more than half of the respondents in Singapore (54.7\%) and the UAE (79.6\%) had plans to do so. Moreover, a considerable percentage of the respondents in these two transit countries were still undecided on whether to stay or move to the next destination.

Such trends were further confirmed by asking the respondents how long they planned to stay in the current destination to work. About $80 \%$ of those in Australia wanted to remain in the country for more than an additional 10 years, and about $70-80 \%$ of those in Singapore and the UAE had shorter-term plans to stay in these countries no more than five additional years. The shorter (mid-term) plans to stay in Singapore and the UAE imply that the respondents consider these countries as transit points, and that they are potential stepwise migrants who will live in multiple destinations over their lifetimes. In contrast, respondents in Australia had a relatively long-term plan for working there; many even indicated "until retirement," which suggests that this country is considered a final destination.

The decision to stay in the current destination or seek greener pastures somewhere else arises from essential differences among the destinations and preferences of the migrants themselves. For one, the destinations differ in their geographical distance from the Philippines, with Singapore being the nearest and the UAE the farthest. Some respondents value the idea that they can go home anytime if they work in Singapore. To be able to land a job as a nurse in Singapore, Australia, or the UAE several years of work experience, either in the home country or in another destination, is required. However, licensing procedures differ. Currently, in Australia, nurses who hold a license and have experience working in previous destinations, such as Canada, New Zealand, the Republic of Ireland, South Africa, the UK, or the USA, are exempted from appearing for the Australia Nursing Board Exam (Australian Health Practitioner Regulation Agency, 2013). On the other hand, Singapore requires that all nurses from the Philippines possess a Philippine nursing license and a recommendation from the employer to be eligible for the Singaporean Nursing Board Exam (Singapore Nursing Board, 2013). Respondents in the study indicated that in Singapore, obtaining a working visa before entering the country is the main pathway available for 
Filipino nurses, whereas in Dubai (UAE), Filipinos can first enter the country to join relatives or as tourists, then take the Nursing Board Examinations after arrival and find employment. If aspirants pass and find an employer within a year, they can be granted a nursing license and a work visa (Dubai Health Authority 2013, p. 53). Australia also provides several pathways for Filipino nurses. They can come as students to enroll in graduate programs in accredited Australian universities, as dependents of a family member who is a migrant, as students taking the bridging program for nurses, and as nurses with a license from an approved country such as the UK, Ireland, or South Africa (Australian Government Department of Immigration and Border Protection, 2013).

In addition to these factors related to geographical distance and the foreign-worker recruitment system, subsequent decisions also depend on how they are accommodated in the destination through multiculturalism policies, the details of which will be discussed in the next section.

\subsection{Multiculturalism policies as a determinant in the choice of transit and final destinations}

Of the different factors that distinguish a transit destination from a final one, multiculturalism policies can be considered crucial, especially from the perspective of the retention of nurses. While Australia has been openly promoting multiculturalism, the UAE and Singapore seem to be strikingly conservative in their policies and practices, as elaborated below. These differences affect migrants' long-term plans rather than the initial decision to migrate.

In the following discussion, countries are classified on a spectrum reflecting the extent to which multiculturalism is implemented and the nature of multicultural policies, with Australia, as an active promoter of multiculturalism and multiculturalism policies toward one end, and Singapore and the UAE toward the other end.

\subsection{1 "Easy entry-easy exit" transit destinations: The case of Singapore}

The recruitment of Filipino nurses to Singapore has been ongoing since the early 1990s, which is later than recruitment to Middle East countries, where Filipino nurses have been employed since the Marcos administration in the 1970s. ${ }^{5}$ Singapore represents a group of destinations that allow easy entry because of its organized recruitment system, in which the private sector, including hospitals and care home administrations as well as private recruitment agencies, are actively involved and are 
cooperative in bringing in foreign nurses (Personal communication with a recruiter in Singapore: March 19, 2008). At the same time, however, nurses consider these destinations only as stepping stones, and their stay in these countries can very well facilitate their easy exit to a more preferred destination.

That it was relatively easy and faster to find work in Singapore compared to the US, Australia, and other receiving countries was evident in the interviews. Because of the acute nursing shortage and need to fill positions as soon as possible, and the efficient and transparent system of processing immigration papers in terms of what documents are needed and the adoption of online application software, the entire recruitment process from application to employment usually takes one to two months, compared to years in the case of the US. Applications can be lodged through relatives in Singapore, partner recruitment agencies in the Philippines, or via the Internet. Compared to their counterparts in other countries, Singaporean employers and the Singapore Nursing Board play a greater role in recruitment. They even come to the Philippines to administer the licensure examination and conduct interviews. The recruitment fee is also less expensive and paid using an easier repayment scheme compared to those in other countries. In 2009, the recruitment fee ranged from $\$ 1,500$ to $\$ 3,000$, which is paid by the Filipino nurses in installments after their arrival in Singapore. It is also relatively easy for Singaporean employers to decide on hiring foreign nurses because they do not pay any fees to the recruiter, and they are also assured that nurses who do not perform well during the six-month probation period can be "returned and replaced with another nurse from the Philippines" (Personal communication with a recruiter in Singapore: March 19, 2008).

While Singapore sets two conditions for institutions to be eligible to hire foreign nurses, these do not seem to hinder their recruitment and employment. Based on Singaporean immigration rules, the recruitment and employment of a foreign nurse depends on two conditions: the total number of foreigners employed does not exceed the quota (called the dependency ratio ceiling), which is generally about $10-15 \%$ of the total workforce in 2008, and also that the employer is willing to pay a monthly foreign worker's levy of about \$250-390. ${ }^{6}$ An administrator of a nursing home, when interviewed in March 2010, emphasized that it is more costly to employ foreign nurses because of the levy and housing and food subsidies. Nevertheless, they are willing to employ foreign nurses because there is a general shortage of nurses owing to the unpopularity of the profession among Singaporeans and that many 
nurses leave nursing either to raise a family or go overseas (Interview with administrator of a nursing home, March, 20, 2008).

While Singapore and some Middle Eastern countries openly and actively recruit foreign workers, their conditions after arrival in the destination are often highly dependent on their salary, job category, nationality, ${ }^{7}$ and type of visa. By setting rules based on these criteria, the government is able to selectively accept "desirable" foreign workers. The foreign workers in Singapore are categorized according to their skills, with domestic helpers and construction workers at the bottom (categorized as unskilled) and skilled professionals on top. Filipino registered nurses are considered "mid-level skilled" workers. They receive an "S pass" visa, ${ }^{8}$ with which they enjoy a greater number of and better privileges than do foreign workers in the construction and other services sectors, but these privileges are fewer and less superior than those afforded to professionals engaged in IT, education and research, pharmaceuticals, and other high value-added sectors. For those who have a "work permit" (domestic helpers, healthcare assistants, and waiters/waitresses) or "S" pass status, the employer has to pay the foreign worker's levy (tax). In contrast, the foreign worker's levy is not required when "professionals" holding an Employment Pass ("E" pass) or Personalized Employment Pass (PEP) are employed.

One of the nurses' privileges concerns family reunification. Nurses can only bring in their immediate family members (spouse and unmarried biological and/or legally adopted children below age 21) as dependents if their monthly fixed salary is at least $\$ 2,800 .{ }^{9}$ While many of the respondents could meet this salary requirement, they chose not to petition for dependent visas because of the high cost of living in Singapore, including costs of housing and children's education, which are not subsidized by the government or by the employer. They are also not allowed to apply for dependent visas for their parents and parents-in-law. Many nurses opt to bring their families in simply for a vacation, since the Philippines is only a three-hour flight from Singapore.

In Singapore, citizenship through naturalization is generally not granted to foreign workers unless they marry a local or there are extraordinary circumstances. ${ }^{10}$ Dual citizenship is strictly disallowed. Application for permanent residency requires that the applicant holds at least an $\mathrm{S}$ pass and proof of employment, but satisfying these requirements is not an assurance that the application will be approved. Permanent residency status is important if Filipino nurses plan to stay in Singapore to work because they can find jobs more easily with this status. In addition, employers prefer permanent residents because they are no longer 
included in the foreign workers' quota and the employer does not need to pay the levy for them. However, ironically, permanent residency is tied to employer sponsorship; the permanent residency and re-entry permit to enter and exit Singapore are both issued with specific validity dates (usually three to five years), and they can only be renewed by showing proof of employment (Immigration and Checkpoints Authority, n.d.).

While there are no official policies discriminating against Filipino nurses in the workplace, respondents claimed that they are at the mercy of the local hospital administrators from the time they arrive in Singapore. Filipino nurses come to Singapore on a temporary/ probationary nursing license issued by the Singapore Nursing Board, which is valid for six months and renewable for another six months. Nurses who do not receive a good evaluation after this period will be repatriated. Those who are initially employed as healthcare attendants or nursing aides need to be promoted first to enrolled nurses and then to registered nurses, both of which depend on the initiative of the employer. If the employer deems their performance unsatisfactory, their initial two-year contract will not be renewed, and they will have to return to the Philippines. They are not allowed to find another employer, unless they leave the country first.

\subsubsection{The preferred "in-between" transit destinations:} The UK and Ireland

Based on the stepwise pathways revealed by the respondents, the UK ${ }^{11}$ and Ireland are considered the more preferred transit destinations for Filipino nurses for many reasons. First, compared to Singapore and the $\mathrm{UAE}$, it is not as easy to enter the UK and Ireland because they have more prohibitive requirements regarding work experience and licensing. Second, access to recruiters for these destinations is quite limited in the Philippines because many are often based in other transit destinations, like Singapore and the UAE, where interviews are also conducted. Third, these destinations offer higher salaries and better benefits than the initial transit destinations.

A last and perhaps most important difference from the initial transit destinations is that these countries provide opportunities for migrant workers to become citizens provided they have lived in the country for a specified period. Obtaining citizenship in these second-transit destinations increases the probability of being hired in a more desired destination because of favorable policies and mutual agreement schemes (such as those among the Commonwealth countries) concerning employment and the status of citizens' stays in these destinations. 
One interviewee from Australia said, "When I was in the UK, everyone was eyeing UK citizenship because we wanted to go to Australia. It was easy for me to come to this country because of my UK passport. In fact, I began working in the wards only a week after arrival." One interviewee in the UK also said, "now that I have a UK passport, I am planning to return to the UAE because I will earn more compared to Filipino nationals there." Further studies are necessary to determine what other "in-between" transit countries are considered by these nurses and how access to citizenship not only affects their decision-making process in choosing destinations, but also influences their identity formation, sense of belongingness, and ideas on nationalism and multiculturalism.

\subsubsection{Final destinations: Australia and USA}

Not surprisingly, the US is the top destination because of its historical and cultural affinity with the Philippines. ${ }^{12}$ Buchan et al. (2005) and Buchan, Jobanputra, \& Gough (2005) observe that a majority of nurses from other source countries are also inclined to target the US as a destination. It is the traditional destination for Filipinos who wish to pursue the American dream, as it has what Paul (2011) calls "place reputation." In addition, the Philippine nursing curriculum is patterned after that of the US, so less adjustment is required in the workplace. A very large Filipino community is also available to support newly arrived nurses. Moreover, that foreign nurses can have varied career options and a clear career pathway in the US contributes to its popularity as a final destination. In a telephone conversation with a Filipino nurse based in Maryland in June 2012, he noted, "while in other countries, there are very few options for nurses, especially Filipino nurses, in the United States there is career development or job promotion. ... Here in the US, if you really work hard, you get recognized, you get promoted, you get compensated, kahit sino ka pa [whoever you are]." Filipino nurses in the US not only find opportunities to work in hospitals, but also in other fields such as home nursing care, medical insurance, and nursing-related businesses. They have assumed important positions where they work, such as vicepresident of a health care company or head nurse in a hospital.

This study also showed that, in addition to the US, Australia was the other country most preferred by respondents. There are several reasons why Filipino nurses want to remain there for long periods. Australia offers one of the highest salaries and best benefit schemes, such as six weeks' annual leave, among the destinations. Opportunities for career growth, citizenship, and family reunification are good, and Australia appeals to personal preferences such as the less severe weather and shorter distance 
to the Philippines compared to the UK and Ireland. Respondents also mentioned Australia's positive environment for raising children and the advantage of having "lots of space" when building a family.

Compared to transit destinations, there are many types of visas and migration pathways available to aspiring nurses, both temporary and permanent, in Australia. ${ }^{13}$ However, for most of these pathways, considerable professional nursing experience and a high level of English language proficiency are necessary to obtain a professional nursing license and tenured employment. However, these language and skills requirements have become more difficult in the past decade. For example, to avail oneself of any of the permanent residency visas, the foreign nurse should achieve a minimum International English Language Testing System (IELTS) score of six points in all skills (reading, writing, speaking, and listening) in one sitting. To apply for most of the visas, the Filipino nurses should be nominated or sponsored by an employer, many of whom prefer nurses who are trained in specialized fields like psychiatric nursing, renal care, or theatre or surgical nursing. An option for those who lack the skills and language is to get a nursing-student visa. However, while there are no initial requirements for skills and language proficiencies, students are required to provide proof of ability to fund their education. Therefore, the easier way to get to Australia is to go initially to a transit destination such as the UK, Ireland, the US, Singapore, or Canada to gain experience and licensure and to save money.

Once employed as registered nurses in an Australian public hospital, the salary, benefits, and labor conditions are the same as those of local nurses. Nurses can negotiate with hospital administrators and the government through the nurses' association, which all nurses are allowed to join. Each state or territory has its own Public Sector Nurses' and Midwives' Enterprise Agreement ${ }^{14}$ that contains provisions regarding the salary, allowed leave, security of tenure, and other labor conditions and is negotiated every three years. Moreover, the nurses' association stands behind its members. One Filipino nurse noted that, "if it were not for the nurses' association, I would have been laid off for alleged incompetency. Ipinaglaban talaga ako ng union [The nurses' association really fought for me]." This kind of support by a professional group and the sense of "belongingness" to a group, which are not readily found in transit countries, are highly appreciated by the Filipino nurses.

Since family reunification has been a vital part of Australian immigration policy, nurses can include their immediate family members in their application for a skilled worker visa, a relative-sponsored visa, or even a student visa. Converting a working visa to permanent residency also 
takes less time compared to many other destinations. One respondent was able to get permanent residence visas for herself and her husband through employer nomination barely a year after migrating to Australia on a working visa. This visa assures her and her family that they can stay and work in Australia on a permanent basis, receive subsidized healthcare, access certain security payments, and be eligible to apply for Australian citizenship. It also gives her family the opportunity to sponsor relatives from the Philippines. Another feature of Australia, being an immigrant country, is that it allows for dual citizenship. For naturalized Philippine-born nurses, this is an advantage if they want to enjoy the rights and privileges of a Filipino citizen, such as owning land and other real estate in the Philippines and long-term stays without the necessity of applying for a visa, while keeping a residence in Australia.

Finally, it is also noteworthy that the respondents cited the multicultural character of Australian communities, in terms of not only hosting migrants from many countries and having ethnic restaurants and groceries, but more importantly, in terms of the national and local government and the workplace providing opportunities to people of different origins and backgrounds to actively interact. For example, multicultural festivals (country days) and seminars are held to promote understanding of varied cultures, and free interpretation services in many languages are provided.

From the discussions above, it is clear that differences in multiculturalism policies in the destinations, particularly with regard to access to the labor market, citizenship, and family reunification, contribute to the stepwise migrant's decision whether to stay in one destination or move to the next one. If a country wants to keep a pool of foreign skilled nurses, especially in light of a serious shortage of nurses owing to demographic issues, the implementation of favorable multiculturalism policies is indispensable. In the following section, we look specifically at Japan, which has yet to find a long-term solution rather than a mere stopgap measure to address the future shortage of skilled nurses in the country.

\subsection{Stepwise migration and multiculturalism: The case of Japan}

\subsubsection{The migration of Filipino nurses to Japan under the JPEPA scheme ${ }^{15}$}

Japan began accepting nurses from Indonesia in 2008 and the Philippines in 2009. Under the provisions of JPEPA, which is a comprehensive treaty covering trade, investments, cooperation, and movement of natural 
persons, Filipino and Indonesian nurses are allowed to come to Japan as "candidate nurses." It took about eight years from the time the negotiations started until it was implemented, partly because the Japanese stakeholders were greatly divided in their opinions about whether and how to accept foreign nurses. Even without gaining national consensus, the agreement was ratified, and the first group of Filipino care-workers and nurses arrived in May 2009.

Under the original agreement, the Philippine government, through POEA, is in charge of recruiting and deploying "candidate" nurses, and the Japanese government, through the Japan International Corporation of Welfare Services (JICWELS) (2013) takes care of these nurses after they arrive in Japan. The Japanese government and Japanese employers share the cost of recruitment, deployment, education, and training, amounting to an estimated US $\$ 40,000$ (excluding an average monthly salary of US $\$ 2,000$ and an annual bonus of 2.6 times the monthly salary) per candidate nurse for three years, the initial period of the contract. If they pass the Japanese National Nursing Licensure Examination (NLE) within three years, then they can stay to work as professional nurses. If they fail, then they are obliged to return to the home country.

Statistics show disappointing results for the scheme in the first four years of its implementation. While the quota for Filipino nurses was set at 200 persons annually, the number deployed did not reach even half of this quota. According to statistical data from the Ministry of Health, Labor and Welfare of Japan (MHLW) (2013) and JICWELS, in the first four years of implementation of the scheme, only 237 were deployed to Japan and only 25 of them (10.5\%) were able to pass the NLE. Moreover, there is high rate of pre-termination of contracts. For example, of the 93 persons who came in 2009, $31(1 / 3)$ had left Japan (Carlos, 2013) before the completion of the initial three-year contract.

There are many reasons cited in the literature to explain this dismal performance, ranging from the language barrier, difficulty passing the licensure examination, difficulties in intercultural communication in the workplace, and other issues that are typical in a multicultural environment or workplace. The hospital employers also complained about the heavy burden imposed on them by the Japanese government to handle the financial expenses (which amount to more than half of the total expenses), education in language and skills, and training and management of the candidate nurses.

The Japanese government has acknowledged these problems and is now working toward several revisions of the scheme. It must be noted, however, that many of the problems identified and the solutions 
offered so far have been made on the assumption and expectation that the nurses will stay and become a stable source of labor in the long run. Below, we argue that Japan is more of a transit destination than a final one. It might not even be chosen as a transit destination given the limited transferrable resources that can be accumulated in this country.

\subsubsection{Is Japan a transit point or a final destination?}

Undoubtedly, Filipino nurses will choose Japan as a destination, but most probably only as a transit point. It is unlikely that Filipino nurses will settle in Japan for good under the current JPEPA scheme because of the country's substantial differences from the other potential final destinations mentioned above.

In addition to the lower salary and benefits in Japan compared to the US, Canada, and Australia, the lack of multiculturalism policies is expected to influence nurses' decisions about whether to remain in Japan. Access to labor in Japan is highly restricted to this government-to-government arrangement and is initially limited to three years and 200 nurses each year. Unlike Australia, there are no other pathways available for nurses educated overseas. Filipino nurses can be treated and compensated as professional nurses only if they pass the difficult licensure examination. In the meantime, they perform in the workplace as assistant nurses or nursing aides. Unlike in Australia, the provisions of the labor contract are mostly left to the decision of the employer. Consequently, especially in the first two years of the implementation of the JPEPA scheme, there was a notably wide gap in the salary and benefits and other labor conditions among the candidate nurses in the same batch.

With regard to family reunification, employers do not allow foreign candidate nurses to bring in even immediate family members. Employers also generally discourage taking long holidays; candidate nurses are allowed only one to two weeks of return leave to visit relatives in the Philippines. Compared to those who are working in Australia and the US, the Filipino nurses in Japan need to pass the licensure examination within a specific period of three years. One revision to this scheme in 2012 allowed for those who did not pass within three years and returned home to come back to Japan on a short-term visa to retake the examination. Obtaining permanent residency is neither easy nor fast. Passing the NLE is a prerequisite, and foreigners with a working visa who do not have a special relationship with the Japanese (such as those who are born in Japan, are former Japanese nationals, or are the spouse or child of a Japanese national) are generally required to have worked in Japan for at least five years, before they are allowed to apply 
for permanent residency (Ministry of Justice of Japan, 2013a). To obtain Japanese citizenship, foreigners have to satisfy numerous requirements and undergo a lengthy procedure, as stipulated in the Nationality Law (Ministry of Justice of Japan, 2013b). Given these conditions, Filipino nurses are not likely to consider Japan as a final destination.

However, Japan does have some qualities similar to those of other transit destinations. The JPEPA scheme provides Filipino nurses with the opportunity to leave the Philippines. They need pay only for their passport, health examination, and other documents required by the Philippine government for all overseas workers (subscription to health insurance and the migrant welfare fund) because the rest-the bulkof the costs for recruitment, deployment, and language and skills education/training are jointly shouldered by the Japanese government and the host institution (hospital). The requirements (a bachelor of science in nursing diploma, a Philippine nursing license, and three years' work experience), which are similar to those of Singapore and other transit destinations, are relatively easy to comply with. Like the other transit countries, Japan shows a trend towards discouraging permanent settlement and favoring a guest-worker migration policy.

One serious concern, however, is that Japan may not even be chosen as a transit destination, especially for those whose main objective in staying in one destination, like Singapore, the UK, Ireland, and the UAE, is to accumulate "transferrable" resources. The skills gained in Japan and the nursing license may not be accepted elsewhere, especially in the potential final destinations. Japanese citizenship, while it takes a considerable time to obtain, may not offer as many privileges as UK or US citizenship, especially in terms of preferential status in some more preferred destinations (like the Middle Eastern countries) in such matters as salary, benefits, and visa status/status of stay. Not even proficiency in the Japanese language, achieved while in Japan, will be useful in the next preferred destination.

Unfortunately, in order to retain foreign nurses, Japan still has much to improve in terms of formulating and implementing the basic multiculturalism policies discussed in this chapter. Moreover, Japan is not largely a country of immigration. Thus, the Japanese, especially the aging generations, generally have limited interaction with and are therefore less accustomed to foreigners in the workplace and serving as care providers. The government has long postponed relaxing immigration rules for foreign workers. While realizing the need for foreign workers to sustain economic development since the 1960s, stakeholders have been divided in their opinions on whether and on what terms 
foreign workers should be admitted. As a result, Japan has welcomed foreigners, not formally as "workers" from the "front doors" but from the "side doors" (spouses of Japanese nationals, industrial trainees, students, and Japanese descendants) and for a time, even from the "back doors" (undocumented foreign workers).

Specifically in the nursing care sector, given the impending serious shortage of nurses due to the aging population and the projected increase in competition to attract and retain foreign nurses, Japan's options may be declining. Unless steps are initiated to solve this problem now, it will be difficult to rely on foreign nurses in 10-15 years when the workforce shortage is expected to reach its peak. While there may be a large international pool of nurses willing to work in Japan, they may not be immediately available to work in Japanese hospitals and nursing homes. This is because, especially in the case of Japan, cultural competency and language proficiency are as important as skills and experience for workers in the nursing sector.

\subsubsection{Circular migration as a mid-term solution?}

In light of these circumstances, what can Japan do to sustain a steady supply of foreign nurses who are not only skilled in their jobs but also culturally and linguistically competent? One way is for this country to adopt a "revolving door" or circular migration policy in which the Filipino nurses are able to go back and forth between the Philippines and Japan to practice their profession. The requirements for passing the NLE could be relaxed to encourage Filipino nurses to take it; for example, administering it partly in English or in simplified Japanese, giving the foreign nurses more chances to pass the examination, or giving more time and resources to prepare. Access to the labor market can be improved by exploring other feasible ways to bring in Filipino nurses, such as granting student loans and/or scholarships to potential nurses or establishing agreements between medical institutions in the Philippines and Japan to develop and share human resources. Like many transit countries, employers can develop a system to assure Filipino nurses that they can return to their home country for a leave longer than one to two weeks as part of their work contract. Given the geographical proximity between Japan and the Philippines, allowing this is an alternative to bringing the families of Filipino nurses to Japan. Filipino nurses should be encouraged to return, and they should be given priority in recruitment. Human relations in the workplace can be improved by giving both Japanese and Filipino nurses opportunities for collaboration and interaction. These could assist the Filipino nurses in gaining appreciation for 
working and living in Japan despite the lack of a Filipino support group or family in the country. These initiatives could very well be undertaken by the private sector rather than the government, which has been limited because of its inability to gain consensus among the domestic stakeholders with regard to employing foreign nurses.

Although these measures might not be an incentive for Filipino nurses to make Japan their final destination, they can help alleviate the shortage of nurses by assuring Japan of a pool of qualified and competent foreign nurses to boost its workforce in the long run. Furthermore, these private initiatives can encourage, and would require, the Japanese government to formulate and implement multiculturalism policies in the following three areas: access to the labor market, access to citizenship, and family reunification. Finally, interaction between Filipino and other foreign workers with colleagues and patients in this service sector will be a good start in promoting multiculturalism in Japan in which "top-down" public policies and "bottom-up" private initiatives work hand in hand to promote migrant integration in this country.

\section{Appendix}

Table A9.1 Stepwise migration pathways of Filipino nurses in Australia, Singapore, and the UAE

\begin{tabular}{|c|c|c|c|c|c|}
\hline \multicolumn{2}{|c|}{ Australia $(n=23)$} & \multicolumn{2}{|c|}{ Singapore $(n=8)$} & \multicolumn{2}{|c|}{ UAE (Dubai) $(n=15)$} \\
\hline $\begin{array}{l}\text { Respondent } \\
\text { number }\end{array}$ & Pathway & $\begin{array}{l}\text { Respondent } \\
\text { number }\end{array}$ & Pathway & $\begin{array}{l}\text { Respondent } \\
\text { number }\end{array}$ & Pathway \\
\hline 3 & $\begin{array}{l}\text { Phil (5) } \\
\text { KSA (5) } \\
\text { Ireland (2) } \\
\text { Australia (9) }\end{array}$ & 1 & $\begin{array}{l}\text { Phil (3) } \\
\text { KSA (1) } \\
\text { Singapore (2) }\end{array}$ & 1 & $\begin{array}{l}\text { Phil (6) } \\
\text { KSA (3) } \\
\text { UAE (6) }\end{array}$ \\
\hline 4 & $\begin{array}{l}\text { Phil (3) } \\
\text { Ireland (8) } \\
\text { Australia (4) }\end{array}$ & 2 & $\begin{array}{l}\text { Phil (6) } \\
\text { KSA (2) } \\
\text { Singapore (12) }\end{array}$ & 8 & $\begin{array}{l}\text { Phil (9) } \\
\text { KSA (1) } \\
\text { UAE (19) }\end{array}$ \\
\hline 5 & $\begin{array}{l}\text { UK (8) } \\
\text { Australia (3) }\end{array}$ & 15 & $\begin{array}{l}\text { Phil (2) } \\
\text { KSA (1) } \\
\text { Phil (2) } \\
\text { Singapore (2) }\end{array}$ & 9 & $\begin{array}{l}\text { Phil (?) } \\
\text { KSA (8) } \\
\text { UAE (17) }\end{array}$ \\
\hline 8 & $\begin{array}{l}\text { KSA (2) } \\
\text { UK (11) } \\
\text { Australia (1) }\end{array}$ & 26 & $\begin{array}{l}\text { Phil (3) } \\
\text { KSA (3) } \\
\text { Singapore (1) }\end{array}$ & 11 & $\begin{array}{l}\text { Phil (5) } \\
\text { KSA (2) } \\
\text { UAE (2) }\end{array}$ \\
\hline 10 & $\begin{array}{l}\text { KSA (10) } \\
\text { UK (3) } \\
\text { Australia (1) }\end{array}$ & 27 & $\begin{array}{l}\text { Phil (5) } \\
\text { Kuwait (4) } \\
\text { Singapore (1) }\end{array}$ & 12 & $\begin{array}{l}\text { Phil (3) } \\
\text { KSA (15) } \\
\text { UAE (3) }\end{array}$ \\
\hline
\end{tabular}


Table A9.1 Continued

\begin{tabular}{|c|c|c|c|c|c|}
\hline \multicolumn{2}{|c|}{ Australia $(n=23)$} & \multicolumn{2}{|c|}{ Singapore $(n=8)$} & \multicolumn{2}{|c|}{ UAE (Dubai) $(n=15)$} \\
\hline $\begin{array}{l}\text { Respondent } \\
\text { number }\end{array}$ & Pathway & $\begin{array}{l}\text { Respondent } \\
\text { number }\end{array}$ & Pathway & $\begin{array}{l}\text { Respondent } \\
\text { number }\end{array}$ & Pathway \\
\hline 11 & $\begin{array}{l}\text { Saipan (2) } \\
\text { KSA (8 mos.) } \\
\text { KSA (12) } \\
\text { Ireland (2) } \\
\text { Australia (9) }\end{array}$ & 37 & $\begin{array}{l}\text { KSA (5) } \\
\text { Singapore (2) }\end{array}$ & 13 & $\begin{array}{l}\text { Phil (7) } \\
\text { KSA (3) } \\
\text { UAE (4) }\end{array}$ \\
\hline 12 & $\begin{array}{l}\text { KSA (13) } \\
\text { UK (2) } \\
\text { Australia (9) }\end{array}$ & 38 & $\begin{array}{l}\text { Phil (1) } \\
\text { Denmark (4) } \\
\text { KSA (0.5) } \\
\text { Singapore (17) }\end{array}$ & 20 & $\begin{array}{l}\text { KSA (15) } \\
\text { UAE (4) }\end{array}$ \\
\hline 14 & $\begin{array}{l}\text { Phil (2) } \\
\text { Singapore (EN 3) } \\
\text { New Zealand (4) } \\
\text { Australia (1) }\end{array}$ & 39 & $\begin{array}{l}\text { Phil (3) } \\
\text { UAE (4) } \\
\text { Singapore (1) }\end{array}$ & 21 & $\begin{array}{l}\text { Singapore (2) } \\
\text { UAE (3) }\end{array}$ \\
\hline 21 & $\begin{array}{l}\text { Afghanistan (1) } \\
\text { UK (8) } \\
\text { Australia (3) }\end{array}$ & 40 & $\begin{array}{l}\text { Phil (4) } \\
\text { KSA (2) } \\
\text { Singapore (15) }\end{array}$ & 22 & $\begin{array}{l}\text { KSA (2) } \\
\text { Taiwan (3) } \\
\text { KSA (2) } \\
\text { UAE (3) }\end{array}$ \\
\hline 22 & $\begin{array}{l}\text { UK (11) } \\
\text { Australia (1) }\end{array}$ & & & 24 & $\begin{array}{l}\text { KSA (4) } \\
\text { UAE (3) }\end{array}$ \\
\hline 25 & $\begin{array}{l}\text { Phil (8) } \\
\text { Ireland (2) } \\
\text { Australia (9) }\end{array}$ & & & 33 & $\begin{array}{l}\text { KSA (4) } \\
\text { UAE (3) }\end{array}$ \\
\hline 26 & $\begin{array}{l}\text { Libya (12) } \\
\text { UK (3) } \\
\text { Australia (14) }\end{array}$ & & & 36 & $\begin{array}{l}\text { Phil (3) } \\
\text { Jordan (2) } \\
\text { Qatar (5) } \\
\text { Phil } \\
\text { (business) } \\
\text { UAE (11) }\end{array}$ \\
\hline 34 & $\begin{array}{l}\text { KSA (3) } \\
\text { Australia (23) }\end{array}$ & & & 39 & $\begin{array}{l}\text { KSA (6) } \\
\text { UAE (3) }\end{array}$ \\
\hline 37 & $\begin{array}{l}\text { Philippines (5) } \\
\text { KSA (2) } \\
\text { Australia (6) }\end{array}$ & & & 43 & $\begin{array}{l}\text { KSA (5) } \\
\text { UAE (10) }\end{array}$ \\
\hline 53 & $\begin{array}{l}\text { USA (8) } \\
\text { Australia (1) }\end{array}$ & & & 48 & $\begin{array}{l}\text { Phil (8) } \\
\text { KSA (10) } \\
\text { UAE (12) }\end{array}$ \\
\hline 59 & $\begin{array}{l}\text { Phil (5) } \\
\text { UK (3) } \\
\text { Australia (11) }\end{array}$ & & & & \\
\hline 62 & $\begin{array}{l}\text { Phil (6) } \\
\text { KSA (9) } \\
\text { Australia (16) }\end{array}$ & & & & \\
\hline
\end{tabular}


Table A9.1 Continued

\begin{tabular}{|c|c|c|c|c|c|}
\hline \multicolumn{2}{|c|}{ Australia $(n=23)$} & \multicolumn{2}{|c|}{ Singapore $(n=8)$} & \multicolumn{2}{|c|}{ UAE (Dubai) $(n=15)$} \\
\hline $\begin{array}{l}\text { Respondent } \\
\text { number }\end{array}$ & Pathway & $\begin{array}{l}\text { Respondent } \\
\text { number }\end{array}$ & Pathway & $\begin{array}{l}\text { Respondent } \\
\text { number }\end{array}$ & Pathway \\
\hline 67 & $\begin{array}{l}\text { Phil (8) } \\
\text { UK (2) } \\
\text { Australia (5) }\end{array}$ & & & & \\
\hline 68 & $\begin{array}{l}\text { Phil (3) } \\
\text { KSA (7) } \\
\text { UK (11) } \\
\text { Australia (3 } \\
\text { months) }\end{array}$ & & & & \\
\hline 69 & $\begin{array}{l}\text { Phil (4) } \\
\text { KSA (10) } \\
\text { Ireland (4) } \\
\text { Australia (1) }\end{array}$ & & & & \\
\hline
\end{tabular}

Notes: Only those respondents who have experience working in at least one overseas destination are included in this table. Numbers in parentheses indicate number of years spent working in the destination (except for Australia Respondent 68).

Source: Author's compilation.

\section{Notes}

All errors remain the responsibility of the author. For correspondence, write to rdcarlos@world.ryukoku.ac.jp.

1. The respondents in this study are holders of Philippine nursing licenses who work as staff nurses and nurse assistants/aides in the destinations.

2. The other forms of integration as articulated by Modood are assimilation, individualist-integration, and cosmopolitanism (Modood, 2013, pp. 146-155).

3. It must be added, however, that for some stepwise migrants, access to citizenship may not necessarily keep them in a destination. It is paradoxical that in some cases, access to citizenship through naturalization drives them to move to a more preferred country that cannot be reached directly from the country of origin due to restrictive, ambiguous, or unpredictable migration policies in the destinations, as argued by Carlos and Sato (2010).

4. The statistics exclude those who did not go through the POEA, such as those who left as tourists, dependents of Filipino migrants overseas, and students.

5. It is not exactly clear when Singapore began actively recruiting nurses from the Philippines. However, the results of the survey show that Filipino nurses were already working in Singapore in 2003-2004.

6. In June 2013, the worker's levy was raised over a staggered period of three years, evidently to moderate the growth of the foreign workforce inflow. For computations of the dependency ratio ceiling and levy per sector, see the Ministry of Manpower, Singapore. http://www.mom.gov.sg/Documents/services-forms/ passes/Schedule_of_Levy_Changes_2013-015.pdf, accessed September 10, 2013. 
7. For example, the approved source countries for the manufacturing sector are China, Malaysia, Korea, Taiwan, and Hong Kong only.

8. For details about the S-pass, see the Ministry of Manpower Singapore website: http://www.mom.gov.sg/foreign-manpower/passes-visas/s-pass/beforeyou-apply/Pages/default.aspx, accessed September 20, 2013.

9. However, this minimum required amount was raised to $\$ 4,000$ in September 2012, making it more difficult for nurses to petition for their immediate family members. Refer to Ministry of Manpower, Singapore (2012).

10. Young foreign men may become Singaporean citizens if they complete the National Service military obligation.

11. For more details about the results of the survey and discussions on the situation and policies in the UK circa 2000, please refer to Carlos and Sato (2010).

12. For details about the history of Filipino nurse migration to the US, see Choi, 2003.

13. The visas available are as follows: (a) Nurses sponsored by an employer (Temporary Work (Skilled) Visa (Subclass 457), Employer Nomination Scheme and Regional Sponsored Migration Scheme); (b) Skilled Migration (Independent migrant, sponsorship by an eligible Australian relative or nominated by a state or territory government); (c) Working holiday; (d) Temporary visa option to do a bridging program to improve skills; (e) Training and Research (Occupational Trainee Stream) Visa; (f) Visitor (Business Stream) Visa (Subclass 600); (g) Student visa (Ministry of Immigration and Citizenship of Australia, 2013).

14. For the current provisions of the Public Sector Nurses and Midwives' Enterprise Agreement in Darwin, Northern Territories, see Office of the Commissioner for Public Employment of Northern Territories, Australia (2013).

15. For details, see Carlos (2013).

\section{References}

Australian Government Department of Immigration and Border Protection (2013). Visa options for nurses. Retrieved from http://www.immi.gov.au/skilled/ medical-practitioners/visa-options-nurses.html.

Australian Health Practitioner Regulation Agency (2013). Overseas practitioners. Retrieved from http://www.ahpra.gov.au/Registration/Registration-Process/ Overseas-Practitioners.aspx.

Banting, K. \& Kymlicka, W. (2012). Is there really a retreat from multiculturalism policies? New evidence from the multiculturalism policy index. The Stockholm University Linnaeus Center for Integration Studies (SULCIS). (No. 2012, p. 4). Retrieved from http://www.su.se/polopoly_fs/1.103206.1349356509!/menu/ standard/file/SUL CIS_WP2012_4.pdf.

Buchan, J., Jobanputra, R., \& Gough, P. (2005). Should I stay or should I go? Nursing Standard, 19(36), 14-16.

Buchan, J., Jobanputra, R., Gough, P., \& Hutt, R. (2005). Internationally recruited nurses in London: Profile and implications for policy. The King's Fund Working Paper. Retrieved from http://www.kingsfund.org.uk/publications/ internationally-recruited -nurses-london. 
Cantle, T. (2012). Interculturalism: The new era of cohesion and diversity. Hampshire, UK: Palgrave Macmillan.

Carlos, M. R. D., Sato, C., \& Caragay, R. (Eds) (2009). The migration of health care workers from the Philippines: Japan as a potential host country for nurses and caregivers. Philippines-Japan Conference on Migration Proceedings. Ryukoku University Afrasian Center for Peace and Development Studies Research Series, 8. Retrieved from http://www.afrasia.ryukoku.ac.jp/jp/research/researchseries8.pdf.

Carlos, M. R. D. (2013). The stepwise international migration of Filipino nurses and its policy implications for their retention in Japan. Afrasian Working Paper Series, 23. Shiga: Ryukoku University Afrasian Research Centre.

Carlos, M. R. D. \& Sato, C. (2010). The multistep migration of nurses: The case of Filipinos in the United Kingdom. Journal of the Socio-cultural Research Institute of Ryukoku University, 12, 5-34.

Carlos, M. R. D., \& Sato, C. (2011). The multistep international migration of Filipino nurses: The propensity to migrate among Filipino nurses in Dubai. Journal of the Socio-cultural Research Institute of Ryukoku University, 13, 37-64.

Choi, C. C. (2003). Empire of care: Nursing and migration in Filipino American history. Durham, NC: Duke University Press.

Dubai Health Authority. (2013). Dubai healthcare professionals licensing guide. (pp. 51-53, p. 112). Retrieved from http://www.dha.gov.ae/EN/SectorsDirectorates/ Director ates/HealthRegulation/MedicalComplaint/Documents/Dubai\%20 Healthcare\%20professional\%20Licensing\%20Guide\%20-\%20Final.pdf.

Dumont, J. -C. \& Zurn, P. (2007). Immigrant health workers in OECD countries in the broader context of highly skilled migration. International Migration Outlook Part III (pp. 161-228). SOPEMI, Paris. Retrieved from http://www.oecd. org/els/ mig/41515701.pdf.

Immigration and Checkpoints Authority Singapore (n.d). Permanent residency services guidelines. Retrieved from http://www.ica.gov.sg/services_centre. aspx?pageid=231.

Japan International Corporation for Welfare Services [JICWELS]. (2013). Gaikokujin kangoshi kaigofukushishi kouhosha ukeireno wakugumi, tetsuduki ni tsuite [Framework and guidelines in the recruitment of foreign candidate nurses and careworkers]. Retrieved from http://www.jicwels.or.jp/files/ H26E59BBDE5868 5E8AAACE6988EE4BC9AE7ACAC1E983A8JICW.pdf.

Kingma, M. (2008). Nurses on the move: Historical perspective and current issues. The Online Journal of Issues in Nursing, 13(2) (Manuscript 1). Retrieved from http://www.nursingworld.org/MainMenuCategories/ANAMarketplace/ ANAPeriodicals/OJIN/TableofContents/vol132008/No2May08/Nurses ontheMove.html.

Matsuno, A. (2009). Nurse migration: The Asian perspective. International Labor Organization. (pp. 1-23). Retrieved from http://www.ilo.org/wcmsp5/groups/ public/---asia/---ro-bangkok/documents/publication/wcms_160629.pdf.

Ministry of Health, Labor and Welfare of Japan [MHLW] (2013). Dai hyakunikai kangoshi kokkashiken goukaku joukyō [Announcement on the successful examinees of the 102nd nurses national licensure examination]. Retrieved from http:// www.mhlw.go.jp/stf/houdou/2r9852000002xz4d-att/2r98 52000002xz8r.pdf.

Ministry of Immigration and Citizenship of Australia (2013). Visa, immigration and refugees: Via options for nurses. Retrieved from http://www.immi.gov.au/ skilled/medical-practitioners/visa-options-nurses.htm. 
Ministry of Justice of Japan [MOJ] (2013a). Eiju kyoka ni kan suru gaidorain [Guidelines concerning permanent residency permit]. Retrieved from http:// www. moj.go.jp/nyuukokukanri/ kouhou/nyukan_nyukan50.html.

Ministry of Justice of Japan [MOJ] (2013b). The nationality law. Retrieved from http://www.moj.go.jp/ENGLISH/information/tnl-01.html.

Ministry of Manpower Singapore (2012). Review of dependent privileges for work pass holders for implementation. Retrieved from http://www.mom.gov.sg/ MOMDoc/ Dependant_Privil eges_FAQ.pdf.

Modood, T. (2013). Multiculturalism. Cambridge, UK: Polity Press.

Office of the Commissioner for Public Employment of Northern Territory, Australia (2013). Northern territory public sector nurses and midwives 2011-2014 enterprise agreement. Retrieved from http://www.ocpe.nt.gov.au/_data/assets/ pdf_file/ 0007/53359/FWA_approved_Nurses_Agreement_2011-2014.pdf.

Paul, A. M. (2011). Stepwise international migration: A multistage migration pattern for the aspiring migrant. American Journal of Sociology, 116(6), 1842-86.

Philippine Overseas Employment Administration [POEA] (n.d.). Overseas employment statistics 2010. Retrieved from http://www.poea.gov.ph/stats/2010_Stats.pdf.

Singapore Nursing Board (2013). Registration/enrollment for foreign trained nurses. Retrieved from http://www.healthprofessionals.gov.sg/content/hprof/snb/en/ leftnav/ registration_practising_certificate/registration_enrolment/internationally_qualified_nurses_midwives.html.

US Citizenship and Immigration Services (2013). Visa retrogression. Retrieved from http://www.uscis.gov/portal/site/uscis/menuitem.5af9bb95919f35e66f61 4176543f6d1a/?vgnextoid=a294b16dedc0f210VgnVCM100000082ca60aRCRD andvgnextchannel=aa290a5659083210VgnVCM100000082ca60aRCRD.

Except where otherwise noted, this work is licensed under a Creative Commons Attribution 3.0 Unported License. To view a copy of this license, visit http://creativecommons.org/licenses/by/3.0/ 